\title{
The Unconscionable Health Gap: A Global Plan For Justice
}

Lawrence O. Gostin

Georgetown University Law Center, gostin@law.georgetown.edu

This paper can be downloaded free of charge from:

https://scholarship.law.georgetown.edu/facpub/376

375 The Lancet 1504-1505 (2010)

This open-access article is brought to you by the Georgetown Law Library. Posted with permission of the author. Follow this and additional works at: https://scholarship.law.georgetown.edu/facpub

Part of the Health Law and Policy Commons, and the International Law Commons 


\title{
GEORGETOWN LAW Faculty Publications
}

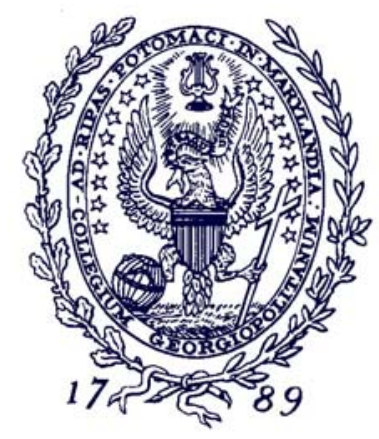

Georgetown Public Law and Legal Theory Research Paper No. 10-39 July 2010

\section{The Unconscionable Health Gap: A Global Plan For Justice}

375 The Lancet 1504-1505 (2010)

\author{
Lawrence O. Gostin
}

The Linda D. and Timothy J. O’Neill Professor of Global Health Law

Georgetown University Law Center

gostin@law.georgetown.edu

This paper can be downloaded without charge from:

Scholarly Commons: http://scholarship.law.georgetown.edu/facpub/376/

SSRN: http://ssrn.com/abstract $=1635902$

Posted with permission of the author 


\section{The Unconscionable Health Gap: A Global Plan for Justice}

International norms recognize the special value of health. The WHO Constitution states that "the enjoyment of the highest attainable standard of health" is a fundamental human right. The right to health, moreover, is a treaty obligation with clear obligations. ${ }^{1}$

Despite robust international norms, unconscionable health disparities exist between the world's rich and poor, causing enormous suffering. The WHO urges "closing the health gap in a generation" through action on the social determinants of health. ${ }^{2}$ As the Marmot Commission observed: "the social conditions in which people are born, live, and work are the single most important determinant of good or ill health." ${ }^{3}$

International health assistance has quadrupled over two decades rising to $\$ 21.8$ billion in $2007 .{ }^{4}$ This level of funding may appear impressive but sits modestly beside the annual $\$ 1.5$ trillion spent globally on military expenditures $(2.43 \%$ of global GDP), and $\$ 300$ billion in agricultural subsidies. Foreign aid simply is not predictable and scalable to needs; and often reflects donors' geostrategic interests rather than the key determinants of health. Developed countries recognize the health gap, but are resistant to taking bold remedial action.

If the health gap is unfair and unacceptable, then how can the international community be galvanized to make a genuine difference? This commentary proposes an international call to action through a Global Plan for Justice-a voluntary compact among states and their partners.

A Global Plan for Justice - a "soft" norm - could be achieved as easily as the passage of a World Health Assembly resolution authorizing the Director-General to negotiate funding, priorities, and implementation. It would not require a treaty or new governance structure, but would encourage WHO to exercise its constitutional powers and leadership.

The Global Plan would set achievable funding targets for a Global Health Fund to be distributed according to need. ${ }^{5}$ Although WHO would negotiate the funding levels, developed countries could donate, for example, $0.25 \%$ of GNI per annum, in addition to current foreign assistance. The total amount countries should give, taking into account both the Global Plan and discretionary funds, would be $0.7 \%$ per annum. OECD countries pledged this level of assistance in 1970, but most have not come close to fulfilling their promise. ${ }^{6}$

The Global Plan would guarantee a universal package of essential services, comprising three core components:

\section{Essential Vaccines and Medicines}


Essential vaccines and medicines "satisfy the priority health care needs of the population." ${ }^{7}$ Yet, 2.5 million people die annually from vaccine-preventable diseases. An additional $\$ 1$ billion would vaccinate $>70$ million children in the 72 poorest countries. ${ }^{8}$ Many poor people also lack access to essential medicines, which is an inexpensive way to treat common infections. Public health emergencies such as Influenza A (H1N1) underscore the crucial need for fair allocation. Governments face intense pressure to protect their own citizens during mass disasters, leaving the poor vulnerable as the rich stockpile life saving vaccines and medicines.

\section{Basic Survival Needs}

Biological interventions have limited impact because they treat only specific diseases. What is truly needed, and which richer countries instinctively do for their own citizens, is to meet basic survival needs, including sanitation and sewage, pest control, clean air and water, tobacco reduction, diet and nutrition, and well-functioning health systems. ${ }^{9}$ Basic needs are a core commitment of the right to health. ${ }^{1}$

\section{Adaptation to Climate Change}

A scientific consensus exists that climate change is anthropogenically forced and impacts ecological systems and human health. Yet, international attention focuses more on emission reductions than adaptation. Disadvantaged populations live on the edge and lack the capacity to ameliorate the devastating effects. Rancorous disagreements marked the Copenhagen summit, with protesters demanding "climate justice." The non-binding accord calls for \$30 billion in aid allocated between mitigation and adaptation. The UN established adaptation funds, but thus far developed countries have pledged only $\$ 300$ million, which is seriously inadequate.

The international community must do more than lament ongoing, unconscionable health inequalities. It must act boldly and with a shared voice, such as through a Global Plan for Justice. If the world does not act, then the avoidable suffering and early death among the world's least healthy people will continue unabated. And that is a breach of social justice that is no longer ethically acceptable.

1 Committee on Economic, Social and Cultural Rights. General Comment 14: The Right to the Highest Attainable Standard of Health Aug. 11, 2000. http://www.unhchr.ch/tbs/doc.nsf/(Symbol)/40d009901358b0e2c1256915005090be?Opendocum ent (accessed Jan. 4, 2010).

2 World Health Assembly. Reducing Health Inequities Through Action on the Social Determinants of Health. May 22, 2009. http://apps.who.int/gb/ebwha/pdf files/A62/A62 R14en.pdf (accessed Jan. 4, 2010). 
3 WHO. Final report of the Commission on Social Determinants of Health. 2008.

http://www.who.int/social determinants/thecommission/finalreport/closethegap how/en/index1.ht ml (accessed Jan. 4, 2010).

$4 \quad$ Ravishankar N, Gubbins P, Cooley RJ et al. Financing of global health: tracking development assistance for health from 1990 to 2007, Lancet 373 (2009), pp. 2113-2124.

5 Ooms G, Hammonds R. Correcting Globalization in Health: Transnational Entitlements Versus the Ethical Imperative of Reducing Aid-Dependency, Public Health Ethics 1 (2008), pp. 154-170.

$6 \quad$ General Assembly of the United Nations. International Development Strategy for the Second United Nations Development Decade - UN General Assembly Resolution 2626 (XXV). October 24, 1970. http://daccess-dds-

ny.un.org/doc/RESOLUTION/GEN/NR0/348/91/IMG/NR034891.pdf?OpenElement (accessed Jan. 4, 2010).

$7 \quad$ WHO. Essential Medicines. 2010.

http://www.who.int/medicines/services/essmedicines def/en/index.html (accessed Jan. 4, 2010).

8 Wolfson LJ, Gasse F, Lee-Martin SP et al. Estimating the costs of achieving the WHOUNICEF Global Immunization Vision and Strategy, 2005-2015, Bulletin of the World Health Organization 86 (2008), pp.27-39.

9 Gostin LO. Meeting Basic Survival Needs of the World's Least Healthy People: Toward a Framework Convention on Global Health, Georgetown Law Journal 96 (2008), pp 331-392. 